\title{
«If you don't believe our story, at least give us half of the money»: Claiming Ownership of the Ok Tedi Mine, PNG
}

Tony Crook

\section{(2) OpenEdition \\ Journals}

Electronic version

URL: http://journals.openedition.org/jso/939

DOI: $10.4000 /$ jso.939

ISSN: $1760-7256$

Publisher

Société des océanistes

\section{Printed version}

Date of publication: 1 December 2007

Number of pages: 221-228

ISBN: 978-2-85430-010-9

ISSN: 0300-953x

\section{Electronic reference}

Tony Crook, « «lf you don't believe our story, at least give us half of the money»: Claiming Ownership of the Ok Tedi Mine, PNG », Journal de la Société des Océanistes [Online], 125 | Année 2007-2, Online since 01 December 2010, connection on 02 May 2019. URL : http://journals.openedition.org/jso/939 ; DOI $10.4000 /$ jso. 939 


\section{«If you don't believe our story, at least give us half of the money»: Claiming Ownership of the Ok Tedi Mine, PNG}

by

\section{Tony CROOK*}

\begin{abstract}
Reports of poor crops, bad tasting water and stories of an ancestral connection with the Mt. Fubilan minesite at Ok Tedi have been reported by people in the Ningerum area since early 1984. In September 2000, a new generation presented a petition on behalf of the West Ningerum Pressure Association. The document had very carefully screened out any traces of customary explanation, and presented the case as if a manifest of poor crops, unfruitful trees, poor water, sparse river life, dried out foliage, and rocks now slippery with moss were the measurable effects of the mine wastes believed to be entering their river systems from underground. It also left out any trace of a tunnel used by spirits and the people who would trade with them and by which fecund water or blessings would flow into the landscape, and left out any trace of the second phase of claiming ownership over the entire mine deposit. This paper analyses these events in terms of regional concerns with revelation and concealment - as if a claim must necessarily comprise both as halves to an equation - and looks at how these concerns are presented in ownership negotiations which depend on eliciting sympathy and recognition of a claim, rather than putting demands into words.
\end{abstract}

Keywords: West Ningerum, Ok Tedi mine, Papua New-Guinea, property, negotiation.

\section{RÉSUMÉ}

Depuis le début de 1984, des gens de la région de Ningerum font état de mauvaises récoltes, d'eau ayant un goût désagréable et d'histoires de liens ancestraux avec le site minier du mont Fubilan à Ok Tedi. En septembre 2000, une nouvelle génération présenta une pétition de la part de la West Ningerum Pressure Association. Le document avait soigneusement éradiqué toute trace d'explication coutumière et présenta le cas comme si les mauvaises récoltes, les arbres qui donnaient peu de fruits, la mauvaise eau, le peu de vie fluviale, le feuillage desséché et les rochers couverts maintenant d'une mousse glissante, étaient les effets mesurables des déchets miniers que l'on soupçonnait d'entrer dans leur système fluvial par des voies souterraines. Il omettait également toute trace d'un tunnel utilisé par les esprits et les gens qui commerçaient avec eux et par lequel de l'eau fertile ou des bénédictions s'écoulaient dans le paysage et toute trace de la deuxième phase de revendication foncière sur la totalité du dépôt de la mine. Cet article analyse ces événements en terme des préoccupations régionales, de révélation et de dissimulation - comme si une revendication devait comprendre les deux moitiés d'une équation - et étudie comment ces préoccupations sont présentées dans les négociations foncières, susceptibles d'éveiller la compassion et la reconnaissance d'une revendication, plutôt que d'être l'expression des demandes.

Mots-ClÉs: West Ningerum, mine Ok Tedi, Papouasie Nouvelle-Guinée, propriété, négociation. 


\section{Revealing the problem}

The Ok Tedi copper mine, situated in Papua New Guinea's Star Mountains close to the international border with Indonesia, is well known for the chronic environmental impacts due to mine waste and tailings disposal into the Ok Tedi river (e.g. World Bank report, 2000), for the legal case pursued by the floodplain Yonggom people through the Australian courts (Kirsch 2006) and for the debate it has stimulated over the position of academic knowledge in what has been termed the «resource wars» (see Ballard and Banks, 2003 for a summary). The court case was a defining moment for the operation and relations in the area - leading to the majority shareholder Broken Hill Propriety (BHP) signalling in 1999 its intention to exit the project, to the World Bank investigation and a government-led consultation with mine-affected communities in 2000. Ultimately, in 2002, BHP reached a settlement to transfer its $52 \%$ equity in the project in exchange for indemnity against liability for long-term environmental damages, and the Ok Tedi $9^{\text {th }}$ Supplemental Agreement or Mine Continuation Agreement was negotiated with downstream affected communities. But even in late 2000, the impact of the Yonggom case on the project was such that when I arrived in Tabubil, one Ok Tedi Mining Limited (OTML) Environment Officer told me that «everything has changed: there are no more stories to tell about Ok Tedi».

My own engagement with the social impacts of the mine had begun in the mid-1990s during an ethnographic study of knowledge-practices, taro horticulture and male cult «secrecy» in the Angkaiyakmin village of Bolivip, located some three days walk east of Tabubil mining township (Crook, 1999), and when in the aftermath of two plane crashes OTML became involved in the rescue operations only to see the mine operations temporarily closed (Crook, 2000). Then, as in what would become known as the Yonggom-led «downstream compensation debate» (Banks and Ballard, 1997), the awkward relations between the PNG State as OTML shareholder and regulator, and the OTML corporation as de facto regional government were deliberately aggravated by local pressure groups attempting to make explicit and pin down these shifting responsibilities. At the time, considerable effort went into masking local internal differentiation, and into precisely differentiating which particular facet of the government and company they wished to activate and make responsible.

In drawing forth one basis for action, then, others had to be temporarily eclipsed (Strathern,
1988). The response to these tragic events brought to the fore and demonstrated the skill with which people across the North Fly region of Western Province were able to perceive, elicit and disguise a division of interests between disputing parties, and also the considerable force lent to relations by making one aspect of them absent. Indeed, as I have argued elsewhere (Crook, 2007), this aesthetic of presenting only «half» and in turn anticipating that there always remains a hidden «half» - such that the effect of what is made «clear» is locally understood to be provided by what remains «hidden» - provides one part of the answer to why anthropology has long taken Min knowledge-practices to be quintessentially about «secrecy» (e.g. Barth, 1975, 1987). But rather than the familiar notion of a separate domain of knowledge providing social solidarity to a separate domain of people (e.g. Herdt, 2003) my argument is that Min knowledge relies for its effects on this form of division whereby what is made «clear» depends on what is «hidden» (to provide a «base» for action), and whereby what is treated as «clear» depends on what is treated as «hidden» (in that moment, for that purpose). In other words, what has otherwise been taken as secret and nonsecret components, is better analysed through Min idioms and as being relatively constituted and context specific.

This article develops and extends these arguments through a study of the West Ningerum Pressure Associations petition (WNPA, 2000) for compensation for damages extending along the full course of two rivers which, although eventually discharging into the Ok Tedi river (south of Ningerum station, north of the Yonggom floodplain), have their headwaters in a geographically separate watershed south of the Mt. Fubilan mine site. The Petition resembles a scientific report, and is a remarkable document for many reasons - amongst them are the forms of evidence offered, the absences of any reference to a cosmological connection between Mt. Fubilan and the fertility of Ningerum lands, nor (as one of the authors was quick to point out) any mention of the Petition's primary ambition: to ultimately claim ownership of the Ok Tedi mine site. Indeed, this absence was held to lend force to this initial compensation claim. The Petition was presented to OTML and the PNG government and, as we will see, had been explicitly written with these actors in mind. My focus is on the WNPA actors who authored the text, their narratives about the design, content and year-long drafting process, on what they had to say about their intentions and ambitions for 
presenting their case in this particular textual form, and on their two-fold strategy that saw them eclipsing the full extent of the damages, any reference to their own customary understandings of the effects, and temporarily eclipsing a planned follow-up move to sue for the ownership of the Ok Tedi mine itself. Alongside these absences, I have elsewhere analysed an analogous tactic (Crook, 2004): one WNPA leader explained how he assumed it was enough to silently present a troubled figure displaying his plight and rely on the authorities to recognize this, and to feel sorrow and think how they might satisfy the people he represented. Of course, this can also look like no claims are being made, rather than a claim on the other party's distinctly-human capacity to think and to feel sorrow.

I am mindful of the caveats raised by Simet ([2005], Director of the PNG National Cultural Commission and involved in formulating cultural and intellectual property rights legislation), in terms of the paradox of legal protection that requires the revelation of resources that depend on remaining concealed. Fieldwork was undertaken in 2000-1, 2004, 2006-7: the first phase was conducted as part of the «Property, Transactions and Creations» project (Hirsch and Strathern, 2004), and focused on how the Ningerum people were putting forward «evidence» for their claims, and responding to new terms of «ownership» coming into currency. By engaging ownership issues around a company miningtownship, the research was widely regarded as participating or intervening in a wider political process. The company struggled with its suspicion of the hidden intentions of anthropologists and its own rhetoric of «transparency». Some Min and Ningerum people interpreted the company's responses to the research as evidence of having touched upon important matters that were deliberately being keep «secret». In taking up the WNPA statement that "If you dont believe our story, at least give us half of the money», then, I am interested in how the WNPA perceived and engaged the language and relations of «cultural and intellectual property rights», and in how a capacity for respectful and reciprocal relations provides the un-stated assumption underpinning their campaign.

\section{What the Petition says}

When the WNPA produced a compensation demand in the form of a scientific report with numbered sections and sub-sections, and relied on the language of «sedimentation» (4.0), «acid rain» (3.2.2), and «over-bank flooding» (6.0), they hoped, by speaking the language of natural science, that their complaints would be readily understood. The «Petition on the demand of compensation claims» sets out its concerns in the following terms:

«The Oktarim, Birim is one of the river systems that has its source within Mount Fubilan in the Star Mountain Ranges where giant Ok Tedi Copper Mine is operated.»

\section{The WNPA Petition argues that:}

«The river system has never been authorized by the State of Papua New Guinea and the business operator (BHP) with due considerations and discussions with the local river communities. Agreements of any sort were never considered and made by concerned parties to cater for any pollution compensation claims that may arise due to mining operations in the future».

«The pollution effects as a result of the mining operations on this river system raised by this Association is a new and important issue that is worth consideration. Despite negative signs of scientific evidence of chemical contaminants, especially that of copper and other trace metals including general water parameters such as $\mathrm{pH}$, alkalinity, etc. recently carried out by Environment Department of the company only after physical changes that have occurred along the river system since 1984.» (Typographical errors in original retained to indicate an editing process at work)

The section concludes with evidence of an apparently different kind: the times and dates on which the Associations complaints were first aired on national television and radio in June 1999. The Petition goes to considerable lengths to provide a complete description of the ways in which the mine and mill operations work, as if demonstrating this knowledge were in itself part of the evidence - rather than simply describing what OTML already knows all-too-well. That is, one of the ways in which the Petition pursues its objective is by revealing these descriptions in an open document, showing that the workings of the operation are no longer hidden from them. At other places, the effect of this knowledge - the effects that the «pollution» has created in other people - and thus gathered people into consideration of one another, is presented directly: for example, section 6.0 «Physical Evidences of Contaminated/Polluted River System» concludes that:

«The above evidence of physical changes along the river system has been observed and concerned raised by the following groups of people.
(i) The Yongoms
(ii) The Awins
(iii) The Irianese
(iv) The Ningerums 
(v) The Missionaries (MCM) Kungim and Tarakbits

(vi) The Missionaries - ECPNG Ok Ao

Therefore the Association now lays down the demand for the compensation claims for the pollution of Oktarim, Birim River system being caused by the giant Ok Tedi Copper Mining operations in the head waters on Mount Fubilan.»

Presenting evidence of the effects that the pollution has had in terms of engaging the interest of a range of social parties might appear to be of an entirely different order to the language of natural science employed elsewhere in the Petition. And yet, the proof of something causing the changes in the rivers is being ascertained here by the effects observable in the landscape, and observable in terms of the knowledge it has created in other people (and the effects it has drawn out of them) - and whose impartiality is drawn upon as witnesses who, in many cases, would not receive any part of a compensation settlement.

The Petition also sets out possible causes of the pollution in Section 3.0. Section 3.1 concerns «Mine Operations», section 3.1.1 concerns «Uncontrolled Mine Waste at Southern and Mosco Dump Sites»:

«The falling waste dumps that includes mostly waste rocks and other materials have covered or buried several streams that used to flow in this area before. This leads to raising an important question; "Have these mine derived contaminated streams escaped to other open river channels?" It is understood that soils in mountainous and sloppy areas such as that of the Star Mountain Ranges, (Mount Fubilan in this case) sit on rocks that are loosely bound and have cracks that can allow water to flow through to other open river channels. This is one important system and common route through which water carrying mine derived wastes such as fine suspended solids and other materials to flow through to Oktarim, Birim River system and consequently affecting it.»

Section 3.1.2 «Drilling and Blasting Operations» suggests that «When dynamites explode, poisonous gases, fumes and dusts are released into the air and cause pollution», and argues that these are «drifted by moving air particles to uncontaminated sites and falls back and settles on water surfaces and plants causing consequent changes/impacts on the natural system». Further suggestions for the path the pollution and sedimentation may be following are detailed as follows:

«[...] Note that there are lots of natural underground passages in this area through which underground contaminated can flow out to other open streams and river waters.»

«In addition, when the rocks are blasted, the earth trembles and causes landslides and massive creaks in the soil and rocks in the affected area that in turn creates pathways for mine derived wastes contaminated streams and waters to flow through and out into other pristine river systems as described in sub-clause 3.1.1. Naturally, disturbed soils/grounds are flushed out and into river waters in the same way.»

Section 3.2 concerns «Mill Operations», 3.2.1 «Waste Chemical Disposal» provides an account of how the Mill operates: "About 6 different chemicals are used in the milling process in the flotation plant»; «these chemicals are added to aid in the recovery process of copper concentrate in two different circuits within the flotation plant» - before again demonstrating knowledge of the products the operation releases into the environment:

«After the process is deemed to be completed, the wastes is discharged together with the tailings. The untreated and not neutralized chemicals in the tailings that flow into the streams than follows the same flow route as described in sub-clause 3.1.1.»

Section 3.2.2 concerns the «Lime Kiln Plant»:

«When Sulphur containing lime stones, are burnt in Lime Kiln Plant, sulphur gases are released into the air and combine with water vapour that form weak sulphuric acid molecules. This product gets dispersed to other areas by moving air particles and falls down as rain droplets (acid rain) and settle on the river changing its chemistry and on plants that may cause their leaves to turn yellow prematurely and fall off and eventually die. One could argue that this becomes an issue only in more industrialized regions but this is still one of the important environmental pollution sources.»

Section 3.2.3 concerns «Uncontrolled Waste Oil and Grease Disposal at Truck Stops»:

«When waste oils and greases enter the river system, they tend to cover the water surface like a sheet of blanket and makes impossible for sunlight and oxygen to get into the water columns to support the available marine life (fish, prawns, etc.). This can lead to serious fish kill problems and overall reduction in the fish biomass and variety which has occurred along the Oktarim, Birim River system to date.»

\section{What the Petition does not say}

In the Petition, the WNPA presented their compensation claim through a carefully considered form that was designed by its authors to be effective as much by what it revealed as by what was concealed. They recounted how it had taken them a year of experiment and re-writing to find the right form of words, and the right form of the report itself to carry their intentions:

«We can put it in our own way, but who is going to understand? - they will not believe in my way of life.» 
In several respects the Petition, which was deliberately presented to the recipient agencies as a complete description of the WNPA's motivating concerns, was also deliberately presented by the WNPA as an incomplete account. There were intentional ommissions - and it should be no surprise that these reveal a particular cultural logic when analysed. One WNPA leader described how, although WNPA had no belief in it themselves, the (mainly Australian) managers of the mine believed in the ability of «science» to measure everything real in the world:

«How can we give them facts and figures to prove our kastam?»

«Its very difficult to put kastam into facts and figures - its invisible, a spiritual thing.»

"We didn't put our history in because it is a different issue. We didn't put these things about our kastam in because we were trying to find the best way [to communicate our concerns]: if we were colonized by Arabs or Indonesians then we would be following others here we follow the Europeans and Christianity, not Hindus. We are following the Western style of living. Putting our kastam inside the Petition would sound useless to Europeans - they want scientific results. Village people will talk about masalai [bush spirits], but Europeans won't believe them - they will say "where is the proof?". But our traditions are still there.»

«Even if the studies prove negative, the company should at least give us half - at least recognise that we don't believe in science and that because of that they should pay us something.»

The WNPA Petition then, leaves many things out, driven by a concern that these other evidences would not be comprehensible to OTML. For example, their concerns are not restricted to the river systems, but extend to the fertility and abundance of garden and forests foods, and to flora and fauna generally: «the water has become tasteless», «skin becomes itchy after bathing», «reduction in number of fish», «taro, sago, banana are unsatisfying», «plants and trees near water-ways are turning yellow», «marita pandanus unlikely to produce much water». Some men also remarked that each generation were becoming smaller than the last (Clark, 1989). The effects that the Petition details for fauna and flora in or nearby to the two river systems are extended in these accounts to include the quality and abundance of garden crops, pigs, marsupials, birds, forest fruit trees and pandanus. The WNPA contention is that the effects of «environmental impact» from the mine site extend to fauna, flora and the landscape in its entirety, not just those aspects immediately adjacent to the two river systems.

When researching these concerns, stories of a connection between the fecundity of the landscape and two spirits dwelling within Mt. Fubilan emerged: one was a creation ancestor, the other a snake called mailim with whom people traded (e.g. by becoming hornbills, by following an underground tunnel whose entrance lies behind a waterfall in the upper Ok Tarim river), and who sent «blessings» (a fecund «water» called okakana) carried by the breeze, by the rain, and by water which increased the growth and «sweetness» of foods:

«There is an underground tunnel leading from inside Mt. Fubilan to the Ok Birim and Ok Tarim river systems. The tunnel is a spiritual route for people who change themselves into birds and animals. The blessings come invisibly.»

«Old people say blessings come from the ancestors. Mt. Fubilan is the place where people collected shells and more blessing for healthy gardens, fish, people Now the spirits in the mountain have been disturbed. Other minor things - like dont eat this, dont eat this [food taboos no longer practiced] - of course, people talk about these things. But now the people who have this knowledge are dying out. People in Ningerum villages will say that the source of blessings, the spirit in Mt. Fubilan has been disturbed, killed.»

«Now our parents believe that the mine waste travels along the spiritual tunnel. The spirit is angry "why did you people let these people come and spoil the mountain?". Some people say that it is the spirit who is sending the poison as a payback - but its hard: the old people think this, but which one are we going to stand up on? Geologists have their own ideas.»

The accounts here, suggest that the effects of sociality, food taboo and ritual are manifested in the very condition of the landscape and the condition for a good community life. The WNPA described a «natural» landscape that changes its physicality depending on the behaviour of the people: just as the growth of plants and the abundance of forest game is affected by ritual, and the weather, so the growth of tree fruits, pigs, plants and people are affected when sociality is practiced in particular ways. It is not the case here that effects in one domain are registered in another, but simply that they are the same domain. The WNPA comments about rocks becoming slippery, and tunnels becoming hidden suggest (as several other aspects of the Petition suggest) that causes in the landscape have left their effects in terms of sociality, and that causes in sociality have left their effects in the landscape.

As Burton has shown (1997: 41ff.), reports of poor crops, bad tasting water and stories of an ancestral connection with the Mt. Fubilan minesite have been reported by people in the Ningerum area since early 1984. A steady flow of letters are received by OTML claiming compensa- 
tion for similar environmental effects from places all over Western Province, and often far removed from the river-systems carrying the mine-sediments. But these «lay filed away in forgotten corners, noted and replied to not effectively absorbed into the intelligence of the organisation» (Burton, 1997: 52), and this suggests that the WNPA's perceptions of the effects registered by their landscape of transformed relations produced by the mine operations are much more widespread. OTML, it seems, knows this too for I was repeatedly told that were they to pay out compensation for something there was no scientific evidence for to one group, then this would open the floodgates to similar claims across the Province.

The OTML Environment Department's response to the WNPA's complaints and later the Petition came in terms of visiting the villages and rivers in January 1999 and again in 2000 when samples were taken from various places in the river valleys and then tested in Tabubil: the results showing nothing out of the ordinary. OTML have been monitoring the fish in the river since 1983, and have acknowledged that there is some effect on migratory fish not being able to reach into this river because of the sedimentation in the Ok Tedi river (as the Petition's section 4.0 «Sedimentation in the OkTedi/Fly River systems» alleges), but no effect on fish resident in the river. OTML argued that there was simply no way that mine waste from the Fubilan pit could be washed down into the Ok Ma valley and then climb over the watershed into the headwaters of the Ok Birim and Ok Tarim rivers. By way of an explanation, one OTML manager used a pen and began drawing on his hand to indicate the lie of the land and where the rivers ran and in which directions, emphasizing that the rivers in question were two water-sheds over from the mine site. During the inspection visits, the officers from the Environment Department took a trip around, looking at what the people wanted to show them. Asked what the people were pointing to as evidence for their complaint, the manager said he thought it was just people jealous of others and wanting to get something for themselves.

The WNPA Petition details, in language that might be comprehensible to Western science, the causal connections between the landscape and Mt. Fubilan which might provide the conduits or paths by which the ill-effects of the mine are travelling. These ill-effects are contended to be now travelling through the same spiritual tunnel that ancestral blessing used to pass through in times when the relations with the ancestral spirit were better. Convinced of the connection between Mt. Fubilan and the fertility and abundance of people and of the flora and fauna generally, the WNPA Petition attempts to detail these «invisible and spiritual» connections which are now bringing ill-effects instead of ancestral blessing, in terms of a causality accessible to Western science.

Consequently, the document had very carefully screened out any traces of customary explanation, and presented the case as if a manifest of poor crops, unfruitful trees, poor water, sparse river life, dried out foliage, and rocks now slippery with moss amounted to the wider consequences of the mine wastes believed to be entering their river systems from underground and along other scientifically measurable conduits. Accordingly, and although premised on a set of cosmological connections, the Petition left out all references to them. The words of their claim were only half the story.

When the WNPA claimed that "If you dont believe our story, at least give us half of the money» they were expecting the respect they gave in framing their compensation claim in terms comprehensible to their adversaries to be appreciated as such, and to be reciprocated by people able to recognize the WNPA's concerns, to feel sorrow for them, and to think about how to satisfy them. Rather than waiting until scientific evidence of pollution thereby also produced evidence of a social relationship defined and constrained to a transaction of compensation, the WNPA took the existence of such a relationship for granted: the Petition amounted to an attempt to have OTML to acknowledge their own part in it, and did so by an acute understanding of how, for the Australian managers, social relationships are constituted by making a particular basis evident. For the WNPA, at least, there was more than a matter of money at stake: its ambition was that good relations and the benefits of «development» would begin to flow once again. The Petition represented a means to reveal to OTML the very basis of their on-going relationship with them (and conveyed in OTML's terms). If there was also a hope that OTML would recognise that they had intervened and were now active participants in a set of cosmological relations (perhaps even substitutes, allies or controllers of the spirit beings) that released various forms of blessings, this was tempered by the knowledge that OTML must already know about them in any case because they obviously knew about the riches contained in Mt. Fubilan and had clearly discovered the means to transact with the spirit beings. 


\section{Claiming ownership of Ok Tedi}

At this point, we see again the WNPA working with an assumption that what they were revealing was already known to OTML. Clearly then, the act of revelation carried a differentiated set of effects from simply knowing the knowledgecontent of the revelation. The attention given to the form of concealment and revelation suggests that these knowledge-practices are motivated by a different aesthetic and a particular epistemology. Were we to focus our attention on «meaning», what was and was-not known, then our comprehension of these relations would be greatly diminished and, I suggest, misconstrue the object of them. It is only by analysing the conjunction of revealed and concealed «halves» that the effects of what we take as «knowledge» can be understood.

We should not be too surprised then, that the WNPA's hidden ambition of claiming ownership of Ok Tedi was itself rather well-known: amongst Wopkaimin royalty recipients, amongst some other Min people and even amongst OTML and PNG government officials. For example, the OTML Executive Manger, Environment and External Relations told me that:

«In most big projects like this, they do thorough studies, genealogies and clan histories. But this was only the second mine, and I'm not sure, I mean I don't know whether all the genealogies were done before $\mathrm{Ok}$ Tedi started. It's a very big problem and a very real problem and I really don't know how we are going to sort that out.»

The oTML Strategic Advisor, Consultation \& Communication (who worked in the area as a government kiap during the project's initial phases) said:

"When I realized that we had members of the same clan either side of the boundary drawn for the Lease for Mining Purposes (LMP), I knew that some day it would come back to haunt us.»

\section{The Tabubil District Manager said:}

«I'd be surprised if those people over the ridge don't have at least some stories about the mountain - there's probably something to their claims - in any case, they have been missed out.»

And yet, because this knowledge had not been acted upon, had elicited no effect, it was treated as though it remained hidden. But there is also a longer history here. For example, land investigations were carried out in the 1970's by government patrol officers and an anthropologist with experience and good relationships in the area. These land investigations did not register any ownership claims to Mt. Fubilan itself amongst the Ningerum peoples. Moreover, it was only in 1984 that the District Officer in Tabubil would record that he had been informed (presumably by the Wopkaimin) that Mt. Fubilan was a sacred site: and commented that its status had not been registered by land investigations stretching back fifteen years by that point.

Equally, the recent appearance of the Ningerum creation story, «History of the Ningerum tribe of Western Province», first compiled in 1983 suggests an important story having been kept deliberately hidden. In fact it had been kept locked away in a filing cabinet «in order to keep it strong», (the story of the origin and efficacy of people and the land also held these capacities), and endangered them if allowed to appear in an inappropriate, open form. For the government's part (in the years leading up to and beyond Independence when the administration was largely staffed by Australian officers), matters of ownership focused upon delineating the areas of leases required for mining, and determining which groups (assumed then to be bounded units of culture, linguistics and territory) were occupying the land. The investigations focused on establishing and reconciling "parish boundaries». What the government were not listening for, the Wopkaimin and Ningerums were not speaking about. Since before the mine began production then, an unwillingness to reveal extremely important stories, whose efficacy derives from keeping them hidden, has been matched by an unwillingness to take such stories seriously.

\section{Conclusion}

The WNPA had taken a decision to divide its campaign into two separate parts: only the first part «environmental impact» is detailed in the Petition. The strategy derives from a contention that this was the immediate problem: «life has become very hard for our people», and that to bring in the second part of the claim would «make the problem too big, and it would take too much time before something could be done for our people». The second part of the WNPA claim (widely known throughout Tabubil) was based on customary accounts, myth and ritual practice, and contends that the ownership of the Mt. Fubilan mine site rightly belongs, at least in part, to the peoples comprising the WNPA. Convinced of the connection between Mt. Fubilan and the fertility and abundance of people and of the flora and fauna generally, the WNPA Petition attempts to detail these «invisible and spiritual» connections which are now bringing 
ill-effects instead of ancestral blessing, in terms of a causality accessible to Western science.

For the WNPA, their «environmental» claim was bolstered by keeping the «landownership» claim concealed - not only by keeping the attentions of OTML and the government undivided by giving them only one thing to think about - but also by retaining «half» of the claim for themselves. Perhaps harder to understand is that the effectiveness of the «landownership» claim was itself preserved by keeping it concealed: not only thereby strengthening the claim that was revealed, but also becoming strengthened itself by virtue of not being made. Of course, it was also further strengthened by being put about in verbal form - informally to others, in settings ostensibly about other subjects - whilst reserving the knowledge, the document and the revelation for an appropriate moment. The WNPA had very carefully differentiated the form in which they made the knowledge available, and were thereby still able to keep in reserve a particular and potent set of effects, despite this «knowledge» also being in circulation. At base, the Petition was an attempt to persuade OTML to recognise and acknowledge to the WNPA that they were indeed already «half» of a relationship with them.

\section{BIBLIOGRAPHY}

BALlARD Chris and Glenn BANKs (eds), 2003. Resource Wars: The Anthropology of Mining, Annual Review of Anthropology 32, pp. 287-313.

BANKs Glenn and Chris BALlard (eds), 1997. The Ok Tedi Settlement: Issues, Outcomes and Implications, National Centre for Development Studies, Pacific Policy Paper 27, Research School of Pacific and Asian Studies, Canberra, The Australian National University, and Resource Management in AsiaPacific, Research School of Pacific and Asian Studies, Canberra, The Australian National University.

BARTH Frederik, 1975. Ritual and Knowledge among the Baktaman of New Guinea, Oslo, Universitetsforlaget.

- 1987. Cosmologies in the Making: A Generative Approach to Cultural Variation in Inner New Guinea, Cambridge, Cambridge University Press.

BURTON John, 1997. Terra nugax and the Discovery Paradigm: How Ok Tedi was Shaped by the Way it was Found and How the Rise of Political Process in the North Fly took the Company by Surprise, in Banks Glenn and Chris Ballard (eds), The Ok Tedi Settlement: Issues, Outcomes and Implications, National Centre for Development Studies, Pacific Policy Paper 27, Research School of Pacific and Asian Studies, Canberra, The Australian National University, and Resource Management in AsiaPacific, Research School of Pacific and Asian Studies, Canberra, The Australian National University, pp. 27-55.

Clark Jeffrey, 1989. The Incredible Shrinking Men: Male Ideology and Development in a Southern Highlands Society, in Healey Christopher J. (ed.), Culture and Development in Papua New Guinea, Canberra Anthropology, special issue v, 12 (1-2). Canberra, Australian National University, Research School of Pacific Studies, Department of Anthropology, pp. 120- 143.

Canberra Anthropology, special issue v, 12 (1-2).

Crook Tony, 1999. Growing Knowledge in Bolivip, Oceania 65 (4), pp. 225-42.

_, 2000. Disputing Resolution: Differing Responses to Two Plane Crashes, in Banks Cyndi (ed.) Developing Cultural Criminology: Theory and Practice in Papua New Guinea, Sydney, Sydney Institute of Criminology Monograph Series 13, pp. 226-252.

-, 2004. Transactions in Perpetual Motion, in Hirsch Eric and Marilyn Strathern (eds), Transactions and Creations: Property Debates and the Stimulus of Melanesia, Oxford, Berghahn Books, pp. 110-131.

-, 2007. Anthropological Knowledge, Secrecy and Bolivip, Papua New Guinea: Exchanging Skin, London, Oxford University Press for The British Academy.

Herdt Gilbert, 2003. Secrecy and Cultural Reality, Ann Arbor, Michigan University Press.

Hirsch Eric and Marilyn strathern (eds), 2004. Transactions and Creations: Property Debates and the Stimulus of Melanesia, Oxford, Berghahn Books.

KIRSCH Stuart, 2006. Reverse Anthropology: Indigenous Analysis of Social and Environmental Relations in New Guinea, Stanford, Stanford University Press.

Simet Jacob, 2005. Re-defining Culture in the Pacific, keynote address, ESfO Conference, Marseille.

Strathern Marilyn, 1988. The Gender of the Gift, Berekeley, University of California Press.

WeSt NINGERUM PRESSURE ASSOCIATION, 2000. Petition on the Demand of Compensation Claims, 27.09.2000.

WORLD BANK, 2000. Ok Tedi - Risk Assessment of Mine Waste Management Project, technical note, Washington, D.C., World Bank. 